\title{
PERKEMBANGAN PEROLEHAN KOMPETENSI PEDAGOGI MAHASISWA PENDIDIKAN TEKNIK DI FAKULTAS TEKNIK UNY
}

\author{
Pardjono $^{1}$, Soenarto $^{2}$, Wardan Suyanto ${ }^{3}$, Putu Sudira $^{4}$, Edy Purnomo $^{5}$ \\ Universitas Negeri Yogyakarta \\ pardjono@uny.ac.id
}

\begin{abstract}
This research aims to reveal the extent of pedagogical-competence of Universitas Negeri Yogyakarta's students as prospective vocational teachers. It will serve as a measure of their readiness to became vocational teachers. The research method was quantitative approach with a descriptive method to present the pedagogicalcompetence profile of the students from each study program. The research population were students from several educational study programs, namely Electronics, Mechanical, and Automotive. Samples of 175 students were taken from each study program's class. The pedagogical competence was evaluated using test questions which instruments have been validated by experts. The result shows that the average competence is 50,24. To breakdown this finding, the averages of pedagogical-competence are 44,71 and 50,60 for students in the $3^{\text {rd }}$ and $5^{\text {th }}$ semester, respectively. The comparison data for the averages of the $3^{\text {rd }}$ to $5^{\text {th }}$ semester students in each study programs are as follows: Electronics are 54,80 to 46,45; Mechanical are 50, 24 and 54,91; and Automotive are 24,18 to 50,72 .
\end{abstract}

\begin{abstract}
ABSTRAK
Penelitian ini bertujuan untuk mengungkap seberapa jauh kompetensi pedagogik mahasiswa calon guru teknik di Universitas Negeri Yogyakarta sebagai ukuran kesiapan mereka untuk menjadi guru kejuruan. Metode penelitian menggunakan pendekatan penelitian kuantatif dengen metode deskriptif untuk menunjukkan profil kompetensi pedagogi dari mahasiswa dari masing-masing program studi. Populasi penelitian adalah mahasiswa Prodi PT. Elektronika, PT. Mesin, dan PT. Otomotif. Sampel diambil masing-masing prodi satu kelas yang berjumlah 175 mahasiswa. Kompetensi pedagogik diukur melalui tes dengan instrumen soal yang telah divalidasi oleh ahli. Hasil penelitian menunjukkan bahwa rerata 50,24. Secara rinci rerata mahasiswa semester 3: 44, 71 dan semester 5: 50,60. Prodi Elektronika rerata kompetensi pedagogi mahasiswa semester 3: 54,80 dan semester 5: 46,45; Mahasiswa Prodi PT Mesin, rerata skor semester 3: 50, 24 dan semester 5: 54,91; Mahasiswa Prodi PT Otomotif semester 3: 24,18 dan Semester 5: 50,72.
\end{abstract}

Kata kunci: kompetensi, perkembangan kompetensi, kompetensi pedagogi, kompetensi mahasiswa.

\section{PENDAHULUAN}

Lembaga Pendidikan Tenaga

Kependidikan (LPTK) sejak awal kemerdekaan sampai saat ini memiliki tugas menyiapkan guru dan tenaga kependidikan. Undang-undang Guru dan Dosen memberikan peluang yang sama antara lulusan pendidikan guru (LPTK) dan pendidikan non guru untuk menjadi guru Sekolah Menengah Kejuruan (SMK). Kebijakan pemerintah tentang guru SMK produktif berkeahlian ganda merupakan kebijakan yang memicu keprihatinan bagi kalalangan LPTK. Alasan darurat dari pemerintah karena kelangkaan guru SMK produktif sementara guru normatif dan adaptif melimpah sempat menenangkan pihak-pihak yang tidak sepakat, namun jangka panjang kebijakan ini miskin dasar argumen akademik.

Penyelenggara Program Studi (prodi) pendidikan teknik, politeknik dan prodi teknik perlu kembali pada peran dan fungsi semula dengan meninjau ulang learning outcome yang dirumuskan. Pihak penyelenggara prodi pendidikan teknik perlu melakukan upayaupaya yang dapat "mengembalikan ruh" lulusan prodi Pendidikan Teknik sebagai 
pencetak lulusan handal untuk menjadi pendidik khususnya di SMK. Salah satu upaya LPTK prodi pendidikan teknik dalam mengembalikan peran dan fungsinya sebagai pencetak guru SMK adalah dengan memastikan lulusannya memiliki penguasaan kompetensi profesional, kepribadian, sosial, dan pedagogi.

Kompetensi profesional calon guru teknik adalah kemampuan vokasional atau practical skills yang sudah lama dikembangkan di LPTK terutama di Fakulas Teknik UNY. Tidak dipungkiri bahwa variasi kemampuan LPTK lain dalam melaksanakan pembelajaran praktik vokasional tidak sama, karena perbedaan kualitas peralatan dan mesin yang dimiliki berbeda beda. Sementara pedagogical content knowledge dari Politeknik yang akan diserahi tugas mengembangkan kompetensi profesional masih dipertanyakan, apakah core knowledge nya adalah engineering atau vokasional. LPTK perlu dikembalikan pada marwahnya dalam mendidik guru teknik dan harus dikembalikan pada tugasnya utamanya secara proporsional dengan melakukan penelitian yang mampu mengungkap keunggulan sekaligus kelemahan dari sistem pendidikancalon guru teknik sejak dalam proses pendidikan.

Kompetensi merupakan faktor penting untuk melihat kemampuan seseorang dalam melakukan pekerjaan dalam bidang keahliannya. Kompetensi bisa dipelajari secara sistematik melalui pendidikan dan pembelajaran maupun secara otodidak. Semua profesi dan pekerjaan termasuk guru memerlukan persyaratan kompetensi. Guru yang mengajar di SMK memiliki latar belakang pendidikan calon guru maupun pendidikan ilmu murni atau non kependidikan. Sistem perekrutan guru ini akhirnya memunculkan dua sistem pendidikan guru yaitu concecutive dan concurrent.

Zais (1976: 6-10) menyatakan bahwa "competence represent the cognitive, affective, and psychomotor learning outcomes established for or by the learner". Definisi ini menjelaskan bahwa kompetensi seseorang terwakili oleh tiga agregat yaitu, kognitif, afektif, dan psikomotorik dari dampak yang dilakukannya. Pendapat lain dari McAshan (1979:45) kompetensi sebagai: “...the knowledges, skills, and abilities or capabilities that a person achieves, which become part of her being to the extent he or she can satisfactory perform particularly cognitive, affective, and psychomotor behaviour ....".

Dalam Standar Kualifikasi Akademik, Kompetensi Pedagogi merupakan kemampuan dalam memahami siswa, perancangan dan pelaksanaan pembelajaran, evaluasi hasil belajar dan pengembangan siswa untuk mengaktualisasikan berbagai potensi yang dimiliki siswa tersebut (Depdiknas, 2006). Secara rinci setiap kompetensi dijabarkan menjadi sejumlah indikator esensial sebagai berikut: (1) memahami siswa dengan memanfaatkan prinsip-prinsip perkembangan kognitif anak, memahami siswa dengan memanfaatkan prinsip-prinsip kepribadian, dan mengidentifikasi bekal ajar awal siswa; (2) merancang pembelajaran, termasuk dalam hal ini adalah memahami landasan pendidikan unuk kepentingan pembelajaran, indikator esensialnya meliputi, memahaki landasan kependidikan, menerapkan teori belajar dan pembelajaran, menentukan strategi pembelajaran berdasarkan karakteristik siswa, kompetensi yang ingin dicapai, dan materi ajar serta menyusun rancangan pembelajaran berdasarkan strategi yang dipilih; (3) melaksanakan pembelajaran memiliki indikator esensial yang mencakup menata latar pembelajaran, dan melaksanakan pembelajaran yang kondusif; (4) merancang dan melaksanakan evaluasi proses dan hasil belajar secara berkesinambungan dengan berbagai metode, menganalisis hasil evaluasi proses dan hasil belajar untuk menentukan tingkat ketuntasan belajar dan memanfaatkan hasil penelitian untuk perbaikan kualitas program pembelajaransecara umum; 
mengembangkan siswa untuk mengakualisasikan berbagai potensinya, memiliki indikator esensial mamfailitasi siswa untuk mengembangkan berbagai potensi non akademika.

Pembelajaran merupakan kegiatan penyampaian informasi yang diciptakan guru untuk memfasilitasi pencapaian tujuan yang spesifik. Smaldino, S.E., et al. (2004: 7), mengatakan bahwa "Instruction is the arrangement of information and environment to facilitate learning." Pembelajaran merupakan kegiatan yang disengaja yang diciptakan untuk memfasilitasi pencapaian tujuan yang diharapkan dan terjadi perubahan tingkah laku peserta didik.

Dalam kegiatan pembelajaran, tujuan yang dicapai bersifat behavioral atau berbentuk tingkah laku yang dapat diamati dan diukur. Tujuan harus dicapai dengan suatu strategi, kegiatan pembelajaran dilaksanakan dalam kondisi yang diciptakan secara sistematis, dengan mengintegrasikan komponen metode, sarana prasarana, media, dan lainnya, sehingga peserta didik mudah dalam mencapai tujuan pembelajaran yang telah ditetapkan. Untuk mencapai tujuan pembelajaran, diperlukan pengajatan yang efektif. Dalam proses pembelajaran terdapat tiga komponen pokok yang saling berinteraksi, yaitu pendidik, peserta didik, dan tujuan pendidikan. Pada pembelajaran kejuruan, proses yang terpenting yakni menjadikan peserta didik sebagai subjek yang harus mengembangkan potensi dirinya berkaitan dengan tujuan yang akan dicapai.

Pembelajaran kejuruan merupakan proses dari peserta didik dalam mengembangkan hidup, belajar dan mendapatkan keterampilan dan kemampuan. Proses ini dilakukan untuk mendukung perubahan peserta didik. Pembelajaran vokasional yang dimaksudkan pada prodi pendidikan teknik adalah pembelajaran yang mengantarkan lulusannya memiliki kompetensi dunia kerja. Pendidikan menengah kejuruan rnisalnya SMK dan MAK. serta dunia kerja bidang keteknikkan merupakan dua dunia kerja dari lulusan prodi pendidikan teknik. Oleh karena itu pembelajaran vokasional prodi pendidikan teknik harus mengembangkan kompetensi kependidikan dan kompetensi keteknikan sekaligus.

\section{METODE}

Penelitian menggunakan pendekatan kuantitatif dengan model survei, dengan menggunakan instrumen pengumpul data test kemampuan pedagogi. Pemaparan hasil penelitian akan dilakukan secara deskriptif. Populasi penelitian adalah semua mahasiswa kependidikan yang ada pada semua Jurusan Fakultas Teknik UNY yang saat ini ada semester 3 dan 5. Penelitian ini menggunakan tiga program studi, yaitu Prodi PT. Elektronika, PT. Mesin, dan PT. Otomotif. Cuplikan populasi diambil masing-masing diambil satu kelas dari dua kelas yang ada. Sampel penelitian berjumlah 175 orang mahasiswa. Metode yang digunakan pada penelitian ini adalah metode tes, dengan menggunakan instrumen soal dan divalidasi oleh ahli. Data yang telah dikumpulkan dianalisis dengan terlebih dahulu di entry ke dalam program Excel. Data ini dianalisis dengan teknik statistik deskriptif dengan mencari Mean, Median, dan Mode. Selain analisis data deskriptif dilakukan dengan mengaitkan antara skor tes kompetensi pedagogi dengan kurikulum yang ada di masing-masing jurusan.

\section{HASIL DAN PEMBAHASAN}

Kompetensi Pedagogi Mahasiswa Pendidikan Teknik Secara Keseluruhan. Hasil analisis menunjukkan bahwa rentang skor kompetensi pedagogik antara 12.5 sampai 75 . Rerata (Mean) nilai kompetensi mahasiswa calon guru pendidikan teknik pada akhir semester 3 dan semester 5 untuk jurusan Pendidikan Elektronika, Pendidikan Teknik Mesin dan Jurusan Pendidikan Otomotif 
adalah: Mean $=47,67$; Median $=50 ;$ Mode: 50; Standar Deviasi $=15,60$.

Tabel 1. Hasil Analisis Data Kompetensi Pedagodik Mahasiswa Semua Jurusan

\begin{tabular}{lr}
\hline Mean & 47,67 \\
Median & 50 \\
Mode & 50 \\
Standard Deviation & 15,60 \\
Kurtosis & $-0,62$ \\
Skewness & $-0,60$ \\
Range & 62,5 \\
Minimum & 12,5 \\
Maximum & 75 \\
Confidence Level $(95,0 \%)$ & 2,32 \\
\hline
\end{tabular}

Skor kompetensi Pedagogik mahasiswa calon guru pendidikan teknik dibagi menjadi 8 (delapan) interval. Terlihat pada tabel bahwa frekuensi paling tinggi ada pada skor interval antara 54-61, yaitu sebanyak 51. Pada diagram batang dari distribusi frekuensi Gambar 1, dapat dilihat distribusi frekuensi setiap interval.

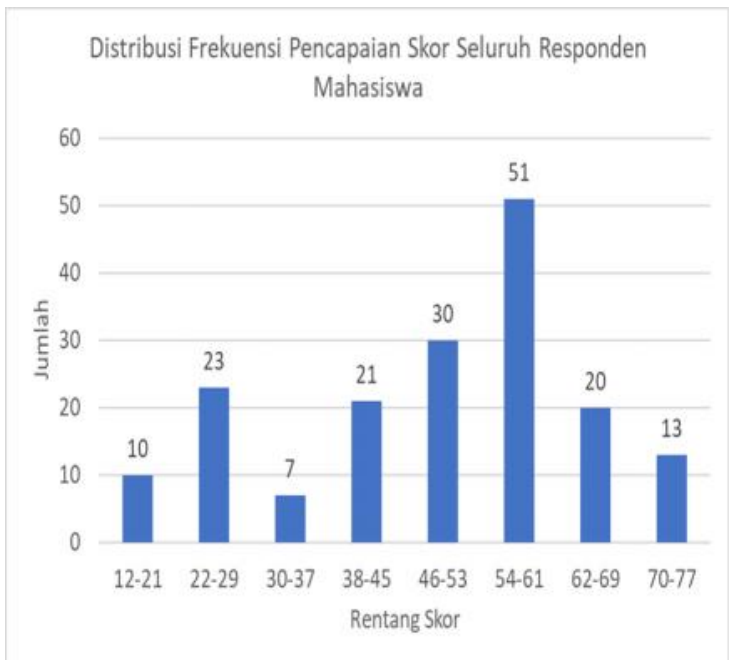

Gambar 1. Diagram Data Kompetensi Pedagogi Mahasiswa Pendidikan Teknik

Kompetensi Pedagogi Mahasiswa Pendidikan Teknik Semester 3. Hasil analisis menunjukkan bahwa rentang skor kompetensi pedagogik antara 12,5 sampai 75. Rerata (Mean) nilai kompetensi mahasiswa calon guru pendidikan teknik pada akhir semester 3 untuk jurusan Pendidikan Elektronika, Pendidikan Teknik Mesin dan Jurusan Pendidikan
Otomotif adalah: Mean $=44,71 ;$ Median $=50$; Standar Deviasi $=16,49$.

Tabel 2. Kompetensi Pedagogik Mahasiswa Pendidikan Teknik UNY Semester 3

\begin{tabular}{lr}
\hline Mean & 44,71 \\
Median & 50 \\
Mode & 59,37 \\
Standard Deviation & 16,48 \\
Sample Variance & 271,91 \\
Kurtosis & $-0,99$ \\
Skewness & $-0,38$ \\
Range & 62,5 \\
Minimum & 12,5 \\
Maximum & 75 \\
Count & 175 \\
Sum & 3890,62 \\
Confidence Level & \\
(95,0\%) & 3,51 \\
\hline
\end{tabular}

Skor kompetensi Pedagogik mahasiswa calon guru pendidikan teknik dibagi menjadi 7 (tujuh) interval atau rentang skor, dari skore minimum 12 sampai dengan skor maksimum 76.

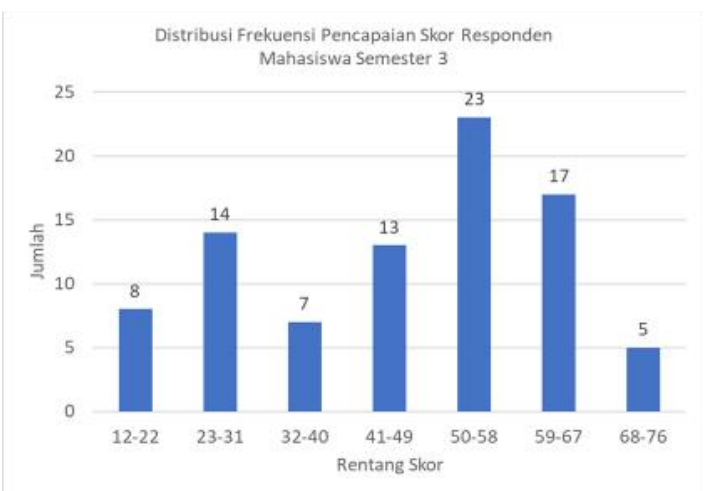

Gambar 2. Distribusi Frekuensi Data Kompetensi Pedagogi Mahasiswa Pendidikan Teknik Semester 3

Pada diagram batang dari distribusi frekuensi Gambar 2, dapat dilihat distribusi frekuensi setiap interval, dimana frekuensi yang paling tinggi adalah dalam interval 5058, sebanyak 23. Untuk frekuensi paling tinggi kedua, yaitu pada interval 59-67 dengan frekuensi 17. Oleh karena itu sesuai dengan hasil ini maka besarnya Mode pada skor pedagogik mahasiswa semester 3 ini adalah 59,37. Nilai skewnes pada tabel 2 adalah 0,383711406, dengan demikian diagram 
distribusi juling ke kiri, artinya lebih banyak skor rendah.

Kompetensi Pedagogi Mahasiswa Pendidikan Teknik Semester 5 Data yang diperoleh dari mahasiswa semester 5, setelah dianalisis mendapatkan hasil sebagai berikut. Rentang skor kompetensi pedagogik antara 12,5 sampai 71, 87. Rerata (Mean) nilai kompetensi mahasiswa calon guru pendidikan teknik pada akhir semester 5 untuk Prodi PT Elektronika, PT Mesin dan Prodi PT. Otomotif seperti berikut. Mean $=50,60 ;$ Median $=53,12$; Standar Deviasi = 14, 17.

Tabel 3. Kompetensi Pedagogik Mahasiswa Pendidikan Teknik UNY Semester 5

\begin{tabular}{lr}
\hline Mean & 50,60 \\
Standard Error & 1,51 \\
Median & 53,12 \\
Mode & 50 \\
Standard Deviation & 14,17 \\
Sample Variance & 200,89 \\
Kurtosis & $-0,025$ \\
Skewness & $-0,80$ \\
Range & 59,37 \\
Minimum & 12,5 \\
Maximum & 71,87 \\
Sum & 4453,12 \\
Count & 88 \\
Confidence Level $(95,0 \%)$ & 3,003114606 \\
\hline
\end{tabular}

Frekuensi paling tinggi pada distribusi skor kompetensi pedagogik mahasiswa pendidikan teknik pada semeter 5 adalah ada pada rentang skor 50-58, yaitu sebanyak 29 . Frekuensi paling tinggi kedua, yaitu pada rentang skor 59-67, yaitu sebanyak 22. Mode pada distribusi skor ini adalah 50 .

Pada diagram batang dari distribusi frekuensi Gambar 3, dapat dilihat distribusi frekuensi dibagi menjadi tujuh rentang skor dan masing-masing dapat dilihat masingmasing rentang skor dan frekuensinya. Frekuensi yang paling tinggi adalah dalam rentang skor 50-58, yaitu sebanyak 29. Untuk frekuensi paling tinggi kedua, yaitu pada interval 59-67 dengan frekuensi 22 dan mode dari tabel 3, yaitu 50. Diagram ini cenderung berbentuk juling ke kanan dengan nilai skewness, yaitu $(-0,800319108)$ (lihat Tabel $3)$.

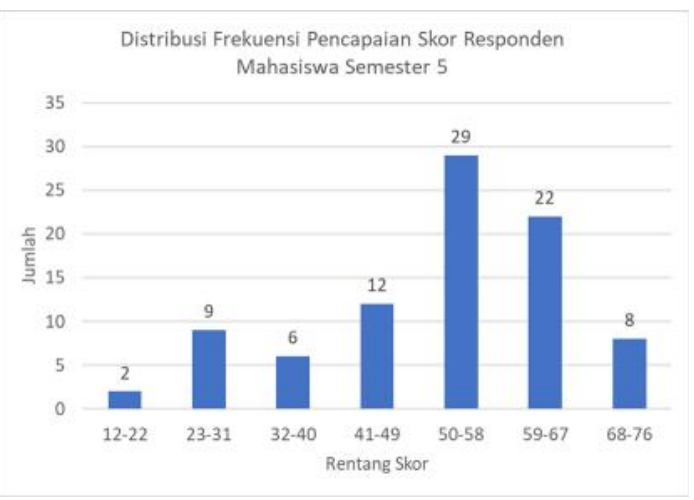

Gambar 3. Distribusi Frekuensi Data Kompetensi Pedagogi Mahasiswa Pendidikan Teknik Semester 5

Kompetensi Pedagogi Mahasiswa Pendidikan Teknik Elektronika Semester 3. Pada sub bab ini dibahas hasil analisis data tentang kompetensi pedagogi untuk mahasiswa pendidikan teknik elektronika semester 3. Data yang diperoleh dari mahasiswa PT. Elektronika Semester 3, setelah dianalisis mendapatkan hasil sebagai berikut. Rentang skor kompetensi pedagogik dengan skor minimum 34,37 dan maksimum 71,87. Rerata (Mean) nilai kompetensi mahasiswa calon guru pendidikan teknik elektronika pada akhir semester 3 adalah: Mean $=54,80$; Median $=$ 56,25; Standar Deviasi = 9, 96 .

Tabel 4. Kompetensi Pedagogik Mahasiswa Pendidikan Teknik Elektronika Semester 3

\begin{tabular}{lr}
\hline Mean & 54,80769231 \\
Standard Error & 1,955259558 \\
Median & 56,25 \\
Mode & 56,25 \\
Standard Deviation & 9,969906643 \\
Sample Variance & 99,39903846 \\
Kurtosis & $-0,634295635$ \\
Skewness & $-0,126921778$ \\
Range & 37,5 \\
Minimum & 34,375 \\
Maximum & 71,875 \\
Sum & 1425 \\
Count & 26 \\
Confidence Level $(95,0 \%)$ & 4,026932441 \\
\hline
\end{tabular}




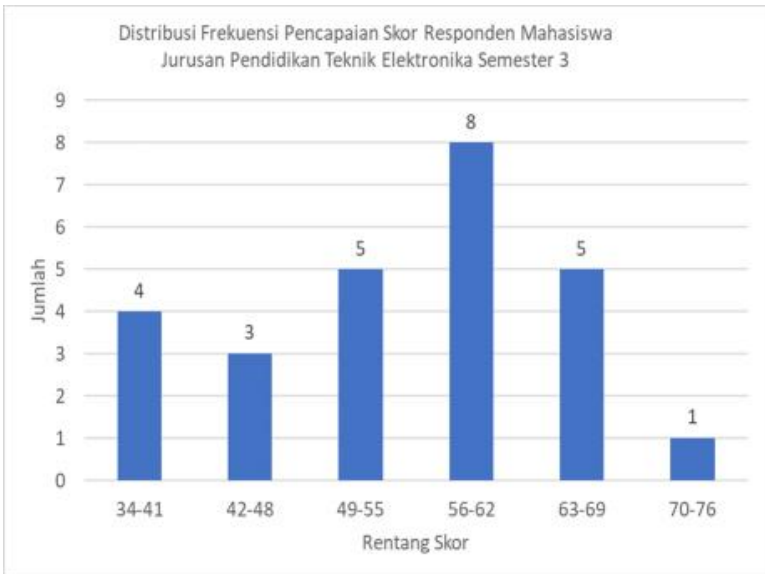

Gambar 4. Distribusi Frekuensi Data Kompetensi Pedagogi Mahasiswa Pendidikan Teknik Elektronika Semester 3

Kompetensi Pedagogi Mahasiswa Pendidikan Teknik Mesin Semester 3. Pada bagian ini dibahas hasil analisis data tentang kompetensi pedagogi untuk mahasiswa Pendidikan Teknik Mesin semester 3. Data yang diperoleh dari mahasiswa P. T. Mesin Semester 3, setelah dianalisis memberikan hasil sebagai berikut. Rentang skor kompetensi pedagogik dengan skor minimum 34, 37 dan maksimum 71, 87. Rerata (Mean) nilai kompetensi mahasiswa calon guru pendidikan teknik elektronika pada akhir semester 3 adalah: Mean $=54,80$; Median $=56,25 ;$ Standar Deviasi = 9, 96 .

Tabel 5. Kompetensi Pedagogik Mahasiswa Pendidikan Teknik Mesin Semester 3

\begin{tabular}{lr}
\hline Mean & 50,24 \\
Standard Error & 1,88 \\
Median & 50 \\
Mode & 59,37 \\
Standard Deviation & 11,61 \\
Sample Variance & 134,80 \\
Kurtosis & $-0,09$ \\
Skewness & $-0,49$ \\
Range & 50 \\
Minimum & 25 \\
Maximum & 75 \\
Sum & 1909,37 \\
Count & 38 \\
Confidence Level $(95,0 \%)$ & 3,81 \\
\hline
\end{tabular}

Frekuensi paling tinggi pada distribusi skor kompetensi pedagogik mahasiswa pendidikan teknik mesin pada semester 3 adalah ada pada rentang skor 53-61, yaitu sebanyak 13. Frekuensi paling tinggi kedua, yaitu pada rentang skor 44-52, yaitu sebanyak 11. Di samping itu dari Tabel 5, mode pada distribusi skor ini adalah 59,37.

Pada diagram batang dari distribusi frekuensi Gambar 5, dapat dilihat distribusi frekuensi dibagi menjadi tujuh rentang skor dan masing-masing dapat dilihat masingmasing rentang skor dan frekuensinya dari frekuensi paling tinggi (13) ke yang paling rendah (1). Diagram menunjukkan kecenderungan distribusi juling ke kanan dengan nilai skewness -0,49 (lihat Tabel 5).

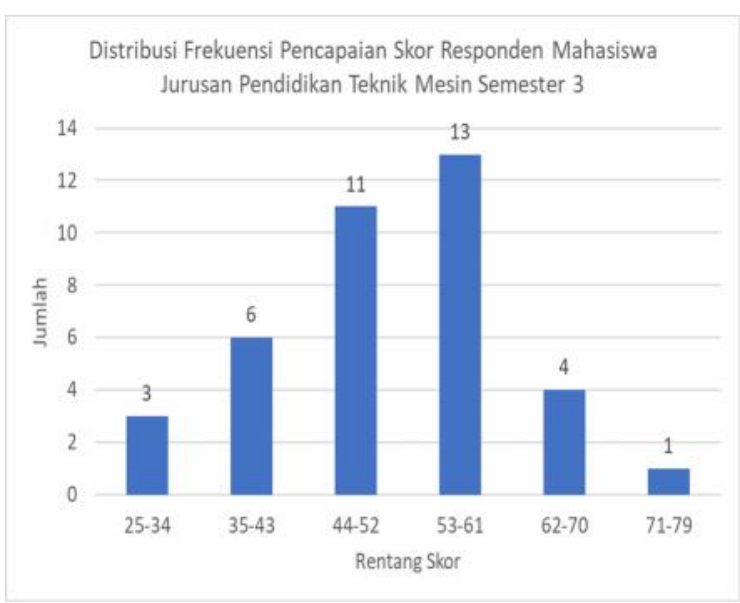

Gambar 5. Distribusi Frekuensi Data Kompetensi Pedagogi Mahasiswa Pendidikan Teknik Mesin Semester 3

Kompetensi Pedagogi Mahasiswa Pendidikan Teknik Otomotif Semester 3. Berikut ini akan dijelaskan kondisi kompetensi pedagogi mahasiswa calon guru teknik bidang keahlian otomotif. Tabel 6 , menunjukkan kompetensi pedagogik dari mahasiswa P. T. Otomotif Semester 3. Rentang skor kompetensi pedagogik dengan skor minimum 12,5 dan maksimum 56,25. Rerata (Mean) nilai kompetensi mahasiswa calon guru pendidikan teknik otomotif pada akhir semester 3 adalah: Mean $=24,18 ;$ Median $=21,87 ;$ Standar Deviasi $=10,45$. 
Tabel 6. Kompetensi Pedagogik Mahasiswa Pendidikan Teknik Otomotif Semester 3

\begin{tabular}{lr}
\hline Mean & 24,18 \\
Standard Error & 2,18 \\
Median & 21,87 \\
Mode & 21,87 \\
Standard Deviation & 10,45 \\
Sample Variance & 109,39 \\
Kurtosis & 3,59 \\
Skewness & 1,81 \\
Range & 43,75 \\
Minimum & 12,5 \\
Maximum & 56,25 \\
Sum & 556,25 \\
Count & 23 \\
Confidence Level $(95,0 \%)$ & 4,52 \\
\hline
\end{tabular}

Frekuensi paling tinggi pada distribusi skor kompetensi pedagogik mahasiswa pendidikan teknik otomotif pada semester 3 adalah ada pada rentang skor 22-29, yaitu sebanyak 11. Frekuensi paling tinggi kedua, yaitu pada rentang skor 12-21, yaitu sebanyak 8. Di samping itu dari tabel 6 , mode pada distribusi skor ini adalah 21,87.

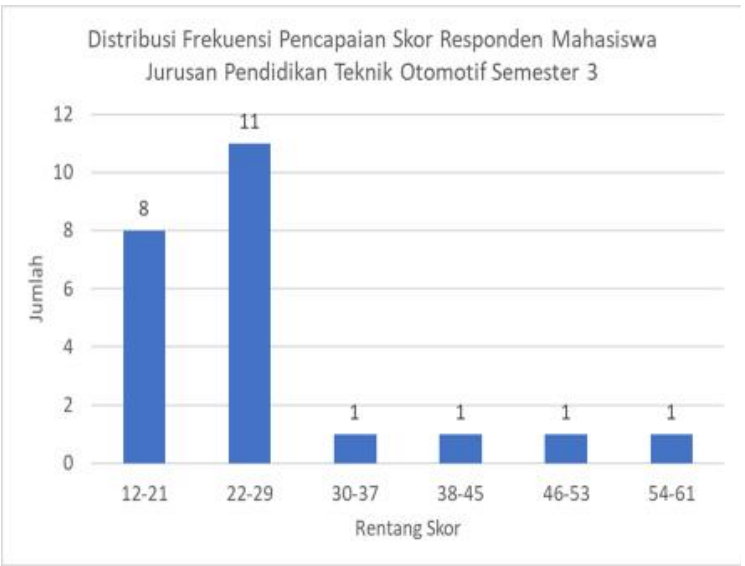

Gambar 6. Distribusi Frekuensi Data Kompetensi Pedagogi Mahasiswa Pendidikan Teknik Otomotif Semester 3

Pada diagram batang dari distribusi frekuensi Gambar 6, dapat dilihat distribusi frekuensi dibagi menjadi enam rentang skor dan masing-masing dapat dilihat masingmasing rentang skor dan frekuensinya dari frekuensi paling tinggi (11) ke yang paling rendah (1). Diagram menunjukkan kecenderungan distribusi juling ke kiri dengan nilai skewness 1,81826035 (lihat Tabel 6). Hal ini menunjukkan bahwa distribusi skor dari kompetensi pedagogik mahasiswa calon guru pendidikan otomotif pada semester 3 , sebagian besar pada nilai, rendah.

\section{Kompetensi Pedagogi Mahasiswa Pendidikan} Teknik Elektronika Semester 5. Berikut ini diuraikan kompetensi pedagogi mahasiswa calon guru teknik bidang keahlian elektronika semester 5. Tabel 13, menunjukkan bahwa kompetensi pedagogik dari mahasiswa P. T. Elektronika Semester 5 berdistribusi sebagai berikut. Skor minimum 12,5 dan maksimum 68,75. Rerata (Mean) nilai kompetensi mahasiswa calon guru pendidikan teknik elektronika pada akhir semester 5 adalah: Mean $=46,45 ;$ Median $=50 ;$ Standar Deviasi $=$ 17, 30.

Frekuensi paling tinggi pada distribusi skor kompetensi pedagogik mahasiswa pendidikan teknik eletronika pada semester 5 adalah ada pada rentang skor 54-63, yaitu sebanyak 10. Frekuensi paling tinggi kedua, yaitu pada rentang skor 44-53, yaitu sebanyak 5 dan rentang skor 12-23 sebanyak 5 .

Tabel 7. Kompetensi Pedagogik Mahasiswa Pendidikan Teknik Elektronika Semester 5

\begin{tabular}{lr}
\hline Mean & 46,45 \\
Standard Error & 3,15 \\
Median & 50 \\
Mode & 62,5 \\
Standard Deviation & 17,30 \\
Sample Variance & 299,52 \\
Kurtosis & $-1,13$ \\
Skewness & $-0,49$ \\
Range & 56,25 \\
Minimum & 12,5 \\
Maximum & 68,75 \\
Sum & 1393,75 \\
Count & 30 \\
Confidence Level $(95,0 \%)$ & 6,46 \\
\hline
\end{tabular}

Di samping itu dari Tabel 7, mode pada distribusi skor ini adalah 62,5. Artinya sebagian besar skor ada pada sekitar skor mode tersebut, seperti ditunjukkan bahwa frekuensi paling tinggi ada rentang skor 54-63. 
Pada diagram dari distribusi frekuensi Gambar 7, dapat dilihat distribusi frekuensi dibagi menjadi enam rentang skor dan masingmasing dapat dilihat masing-masing rentang skor dan frekuensinya dari frekuensi paling tinggi (10) ke yang paling rendah (3). Diagram menunjukkan kecenderungan distribusi juling ke kiri dengan nilai skewness -0,49507056 (lihat tabel 7). Hal ini menunjukkan bahwa distribusi skor dari kompetensi pedagogik mahasiswa calon guru pendidikan elektronika pada semester 5 cenderung untuk juling ke kanan, yaitu sebagian besar mendapatkan skor tinggi.

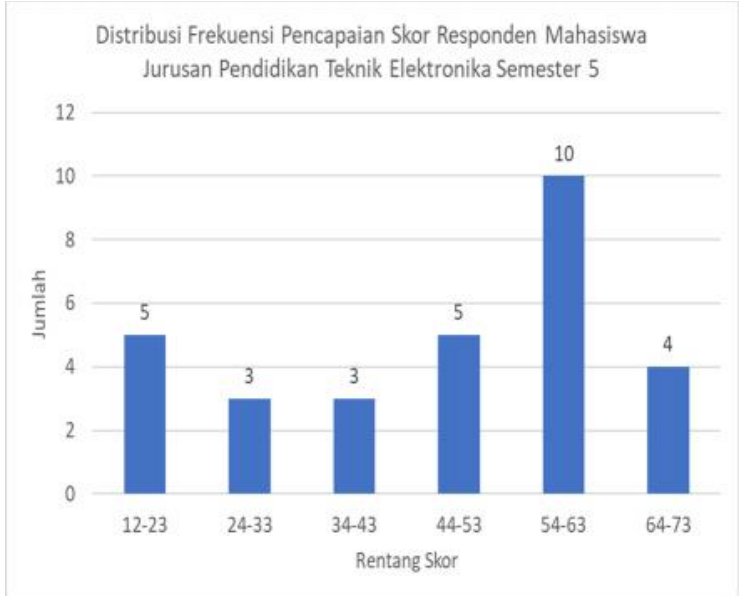

Gambar 7. Distribusi Frekuensi Data Kompetensi Pedagogi Mahasiswa Pendidikan Teknik Elektronika Semester 5

Kompetensi Pedagogi Mahasiswa Pendidikan Teknik Mesin Semester 5. Selanjutnya, akan diuraikan kompetensi pedagogi mahasiswa calon guru teknik bidang keahlian teknik mesin semester 5. Tabel 15, menunjukkan bahwa kompetensi pedagogik dari mahasiswa P. T. Mesin Semester 5 berdistribusi seperti berikut. Skor minimum 40,62 dan maksimum 68,75. Rerata (Mean) nilai kompetensi mahasiswa calon guru pendidikan teknik mesin pada akhir semester 5 adalah: Mean $=54,91$; Median $=53,12$; Standar Deviasi = 6, 44.

Frekuensi paling tinggi pada distribusi skor kompetensi pedagogik mahasiswa pendidikan teknik mesin pada semester 5 adalah ada pada rentang skor 52-56, yaitu sebanyak 9. Frekuensi paling tinggi kedua, yaitu pada rentang skor 57-61 yaitu sebanyak 7. Nilai mode dari tabel 8 menunjukkan pada angka 53,12, diambil dua digit di belakang koma.

Tabel 8. Kompetensi Pedagogik Mahasiswa Pendidikan Teknik Mesin Semester 5

\begin{tabular}{lr}
\hline Mean & 54,91071429 \\
Standard Error & 1,218058448 \\
Median & 53,125 \\
Mode & 53,125 \\
Standard Deviation & 6,445359473 \\
Sample Variance & 41,54265873 \\
Kurtosis & 0,244758298 \\
Skewness & 0,135823385 \\
Range & 28,125 \\
Minimum & 40,625 \\
Maximum & 68,75 \\
Sum & 1537,5 \\
Count & 28 \\
Confidence Level $(95,0 \%)$ & 2,499249495 \\
\hline
\end{tabular}

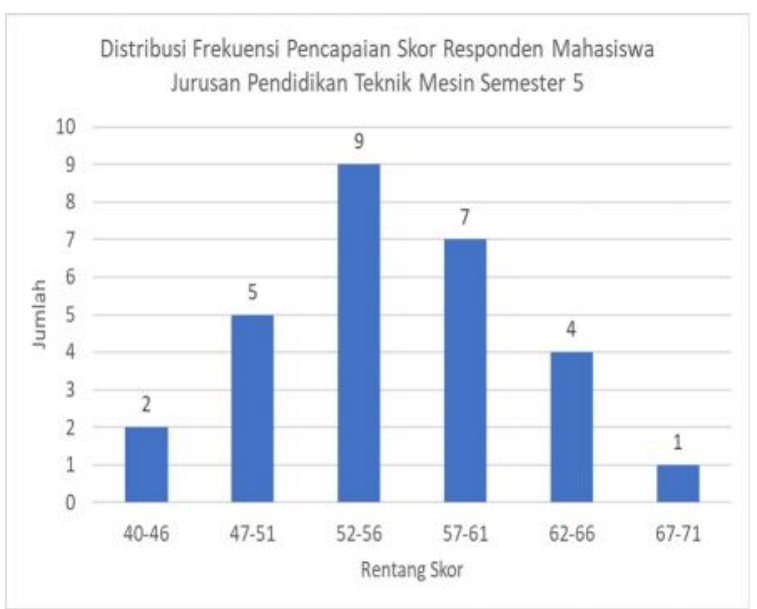

Gambar 8. Distribusi Frekuensi Data Kompetensi Pedagogi

Pada diagram dari distribusi frekuensi Gambar 8, dapat dilihat distribusi frekuensi dibagi menjadi enam rentang skor dan masingmasing frekuensi untuk setiap rentang skor. Dari diagram dapat ditunjukkan bahwa frekuensi paling tinggi (9) ke yang paling rendah (1). Diagram menunjukkan kecenderungan distribusi juling ke kanan dengan nilai skewness 0,135823385 (lihat tabel 8). Nilai skewness kecil positif, hal ini 
menunjukkan bahwa distribusi skor dari kompetensi pedagogik mahasiswa calon guru pendidikan mesin pada semester 5 , cenderung membentuk kurva normal, karena distribusi skor paling banyak ada pada rentang skor antara 47-51; 52-56 dan 57-61, yaitu secara keseluruhan sebanyak 21 dari total 28.

Kompetensi Pedagogi Mahasiswa Pendidikan Teknik Otomotif Semester 5. Selanjutnya, diuraikan kompetensi pedagogi mahasiswa calon guru teknik bidang keahlian otomotof semester 5. Tabel 9, menunjukkan bahwa kompetensi pedagogik dari mahasiswa P. T. Otomotif Semester 5 berdistribusi seperti berikut.

Tabel 9. Kompetensi Pedagogik Mahasiswa Pendidikan Teknik Otomotif Semester 5

\begin{tabular}{lr}
\hline Mean & 50,72 \\
Standard Error & 2,76 \\
Median & 50 \\
Mode & 25 \\
Standard Deviation & 15,12 \\
Sample Variance & 228,77 \\
Kurtosis & $-0,81$ \\
Skewness & $-0,36$ \\
Range & 50 \\
Minimum & 21,87 \\
Maximum & 71,87 \\
Sum & 1521,87 \\
Count & 30 \\
Confidence Level $(95,0 \%)$ & 5,64 \\
\hline
\end{tabular}

Skor minimum 21,87 dan maksimum 71,87. Rerata (Mean) nilai kompetensi mahasiswa calon guru pendidikan teknik mesin pada akhir semester 5 adalah: Mean $=50,72$; Median = 50; Standar Deviasi = 15,12.

Tabel 9, menujukkan bahwa frekuensi paling tinggi pada distribusi skor kompetensi pedagogik mahasiswa pendidikan teknik otomotif pada semester 5 adalah ada pada rentang skor 41, 49; 50-58; dan 59-67 masingmasing memiliki frekuensi 6 . Nilai mode dari tabel 17 adalah 25 .

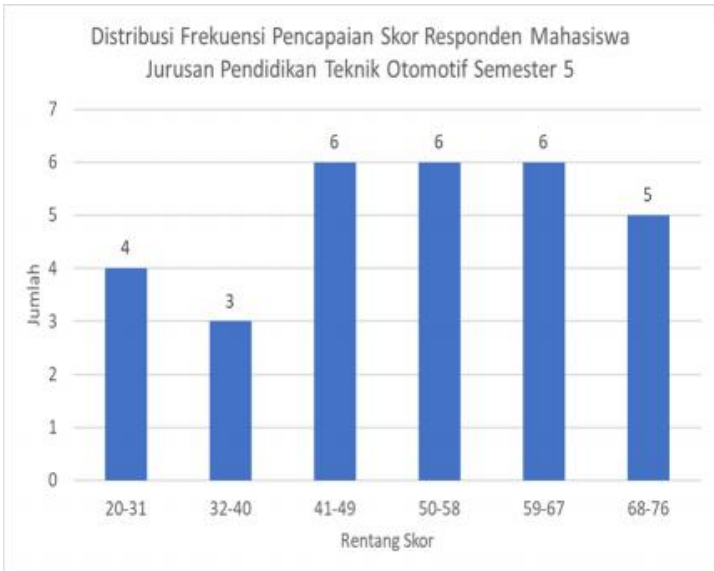

Gambar 9. Distribusi Frekuensi Data Kompetensi Pedagogi Mahasiswa Pendidikan Teknik Otomotif Semester 5

Pada diagram Gambar 8 ditunjukkan bahwa distribusi frekuensi dibagi menjadi enam rentang skor dan masing-masing frekuensi untuk setiap rentang skor dapat dilihat pada diagram tersebut. Dari diagram dapat ditunjukkan bahwa frekuensi paling tinggi (6) ke yang paling rendah (3). Diagram menunjukkan kecenderungan distribusi juling ke kanan dengan nilai skewness -0,36 (lihat tabel 9). Nilai skewness cukup besar dan bernilai negatif. Hal ini menunjukkan bahwa distribusi skor dari kompetensi pedagogik mahasiswa calon guru pendidikan otomotif pada semester 5 , cenderung membentuk kurva juling ke kanan, karena distribusi skor paling banyak ada pada rentang skor antara 41-49; 50-58; dan 59-67, dan masing-masing frekuensinya 6 . Selain itu pada rentang skor 68-76 memiliki frekuensi 5. Bila ditotal maka skor dengan frekuensi tinggi dan tinggi kedua ada 23 dari keseluruhan 30 mahasiswa. Ini menunjukkan bahwa kemampuan pedagogik mahasiswa calon guru bidang keahlian otomotif pada semester 5 sebagian besar tinggi, yaitu sekitar $77 \%$.

Secara umum hasil analisis data menunjukkan bahwa kompetensi pedagogik mahasiswa pendidikan teknik menunjukkan kenaikan dari tahun ke tahun, yaitu dilihat dari pengukuran pada akhir semester 3 dan semester 5. Dari hasil analisis pada seluruh 
sampel ditunjukkan bahwa angka rerata (mean) mahasiswa semester 3 adalah 44, 71 dan 50,60 untuk semester 5. Ini menunjukkan kenaikan kompetensi pedagogi mahasiswa calon guru dari hasil pendidikan pada akhir semeter 3 dan akhir semester 5. Bila dilihat dari skewness masing-masing distribusi, maka bisa dikemukakan bahwa skewness skor untuk semester 3 adalah $-0,38$ dan semester 5 adalah $-0,80$. Nilai minus pada skewness menunjukkan kecenderungan skor berdistribusi pada juling ke kanan. Artinya semakin banyak skor dari pedagogi dari mahasiswa yang ada pada skor yang tinggi dan semakin tinggi. $0,80>-0,38$ menujukkan ada kenaikan jumlah mahasiswa yang memiliki skor tinggi.

Dari hasil penelitian yang telah diuraikan di atas dapat disimpulkan bahwa, rerata skor tes kompetensi pedagogi pada semester 3 dari mahasiswa pendidikan teknik elektronika adalah dengan rerata 54,80 dan pada semester 5 dengan rerata 54,91. Dilihat dari nilai rerata, ada perkembangan kemampuan pedagogi yang positif dari mahasiswa pendidikan teknik elektronika bila dilihat dari nilai rerata yang semakin tinggi. Selain itu dilihat pula dari nilai skewness distribusi skor, bahwa pada semester 3 skewnessnya adalah $-0,12$ dan semester 5 , nilai skewness semakin tinggi, yaitu $-0,49$. Ini menunjukkan ada perkembangan jumlah mahasiswa yang berkemampuan pedagogik tinggi, karena kurva cenderung ke kanan. Selain itu bisa dilihat juga prosentasi mahasiswa dengan skor tinggi di atas rerata pada rerata sebanyak $73 \%$ (19 dari 26) dan semester 5 adalah 63\% (19 dari 30).

Untuk mahasiswa pendidikan teknik mesin, Rerata skor kompetensi pedagogik semester 3 adalah 50,24 dan semester 5 adalah 54,91 . Ini juga menunjukkan kenaikan rerata skor kemampuan pedagogi. Dengan demikian ada dampak positif pembelajaran matakuliah kelompok pedagogi yang ada pada program studi PT. Mesin. Dilihat dari nilai skewness, mahasiswa semester 3 adalah $-0,49$ dan semester 5 adalah $-0,13$. Dengan demikian pada semester 3, lebih banyak mahasiswa yang memiliki skor di atas rerata dan pada rerata karena distribusi cenderung juling kanan. Sebaliknya pada semester 5, skor kompetensi pedagogi membentuk kurva normal, meskipun skewness tidak nol, tetapi bernilai minus tetapi kecil, (-0,13). Jumlah mahasiswa yang memiliki skor di atas rerata, masing-masing, semester 3 adalah $76 \%$ dan semester 5 adalah 75\%. Ini menunjukkan perkembangan positif dari kompetensi pedagogi dari mahasiswa PT Mesin.

Mahasiswa PT Otomotif menunjukkan perkembangan yang berbeda dengan mahasiswa PT. Elektronika dan PT Mesin. Untuk mahasiswa pendidikan teknik otomotif, rerata skor kompetensi pedagogik semester 3 adalah 24,18 sedangkan semester 5 adalah 50,72. Bila dilihat dari skor rerata ini kenaikannya sangat tinggi, dan yang menarik skor rerata mahsiswa semester 3 rendag dibandingkan mahasiswa dari dua prodi yang lain. Dengan demikian ada dampak positif pembelajaran matakuliah kelompok pedagogi yang ada pada program studi PT. Otomotif pada semester 4 dan semester 5 berdampak sangat tinggi terhadap mahasiswa. Dilihat dari nilai skewness, mahasiswa semester 3 adalah $+1,18$ dan semester 5 adalah $-0,36$. Dengan demikian pada semester 3, lebih banyak mahasiswa yang memiliki skor di bawah rerata karena kurva cenderung juling ke kiri. Sebaliknya pada semester 5, skor kompetensi pedagogi membentuk kurva juling ke kanan cukup tinggi. Jumlah mahasiswa yang memiliki skor di atas rerata, semester 3 hanya $8.6 \%$ dan pada semester 5 naik drastia yaitu $56,7 \%$. Ini juga menunjukkan perkembangan positif kompetensi pedagogi dari mahasiswa PT Otomotif dan diperkirakan dampak dari proses pembelajaran dan kurikulum pada prodi ini.

Tidak ada perbedaan kurikulum mata kuliah kependidikan di Fakultas Teknik Universitas Negeri Yogyakarta. Termasuk dalam hal ini adalah struktur dari kurikulum mata kuliah kependidikan yang memiliki 
tujuan memberikan dasar-dasar kompetensi pedagogi adalah sama. Oleh karena itu, adanya perbedaan kompetensi masing-masing prodi diperkirakan berpengaruh pada proses pembelajaran dan karakteristik mahasiswa masing-masing yang berbeda.

\section{SIMPULAN}

Hasil sajian data dan pembahasan menunjukkan bahwa: a) Kompetensi pedagogi mahasiswa calon guru teknik adalah cukup tinggi. Rata-rata skor 50, 24 dan jumlah mahasiswa yang memiliki skor sama dengan rerata dan di atas rerata adalah $65,14 \%$. Hal ini juga dikuatkan dengan nilai skewnes distribusi yaitu -0.60 yang menunjukkan kurve juling kanan, yang berarti sebagian besar mahasiswa berkemampuan pedagogi di atas rerata, b) Ada perkembangan dari kompetensi pedagogi mahasiswa bila dilihat dari tahuan ke tahun. Pada akhis semester 3 rerata skor kompetensi pedagogi adalah 44, 71, dan semester 5 adalah 50,60. Hal ini menujukkan adanya perkembangan kompetensi pedagogi dilihat dari tahun ke tahun dan c) Pada umumnya ada perkembangan kompetensi pedagogi ke arah positif, bila dilihat dari skor rerata keculi prodi PT. Elektronika, yaitu retata semester 3 adalah 54, 80 dan semester 5 adalah 46, 45. Untuk Prodi PT Mesin, rerata semester 3 adalah 50, 24 dan semester 5 adalah 54, 91. Sedangkan mahasiswa PT. Otomotif, rerata semester 3 adalah 24, 18 dan semester 5 adalah 50, 72 .

\section{DAFTAR RUJUKAN}

Mendiknas (2006). Standar kualifikasi akademik dan kompetensi guru. Jakarta: Depdiknas.

McAshan, H. H. (1979). Competency-based education and behavioral objectives. Englewoods Cliffs: Educational Technology.

Smaldino, S.E., et al. (2004). Instructional Technology and Media for Learning. New Jersey: Pearson.

Zais, R. S. (1976). Curriculum: Principles and foundations. New York: Harper \& Row. 